Published in final edited form as:

Bioconjug Chem. 2016 January 20; 27(1): 54-58. doi:10.1021/acs.bioconjchem.5b00625.

\title{
Stable Evans Blue Derived Exendin-4 Peptide for Type 2 Diabetes Treatment
}

\author{
Yi Liu ${ }^{\dagger, \ddagger}$, Guohao Wang ${ }^{\S}$, Huimin Zhang ${ }^{\ddagger}$, Ying Ma ${ }^{\ddagger}$, Lixin Lang ${ }^{\ddagger}$, Orit Jacobson ${ }^{\ddagger}$, Dale O. \\ Kiesewetter ${ }^{\ddagger}$, Lei Zhu§, Shi Gao ${ }^{\dagger}$, Qingjie Ma ${ }^{*} \dagger$, and Xiaoyuan Chen ${ }^{*}, \ddagger$ \\ †China-Japan Union Hospital of Jilin University, Changchun, Jilin 130033, China \\ FLaboratory of Molecular Imaging and Nanomedicine (LOMIN), National Institute of Biomedical \\ Imaging and Bioengineering (NIBIB), National Institutes of Health $(\mathrm{NIH})$, Bethesda, Maryland \\ 20892, United States \\ $\$ C e n t e r$ for Molecular Imaging and Translational Medicine, State Key Laboratory of Molecular \\ Vaccinology and Molecular Diagnostics, School of Public Health, Xiamen University, Xiamen, \\ 361102, China
}

\begin{abstract}
In the treatment of type 2 diabetes mellitus, it is very important to develop therapeutics with prolonged circulation half-life. Exendin-4 is a glucagon like peptide-1 receptor (GLP-1R) agonist that has been modified in different ways for imaging insulinoma and for treating type- 2 diabetes. In this work, we synthesized a maleimide derivative of truncated Evans blue dye (MEB-C3-Mal) to conjugate with $\left(\mathrm{Cys}^{40}\right)$ exendin-4 to obtain a highly stable MEB-C3-(Cys $\left.{ }^{40}\right)$ exendin-4 (denoted as Abextide II). Through in situ binding with endogenous albumin, Abextide II lowers blood glucose level and prolongs the hypoglycemic effect in a type 2 diabetes mouse model more than the FDA approved Albiglutide.
\end{abstract}

\section{Graphical Abstract}

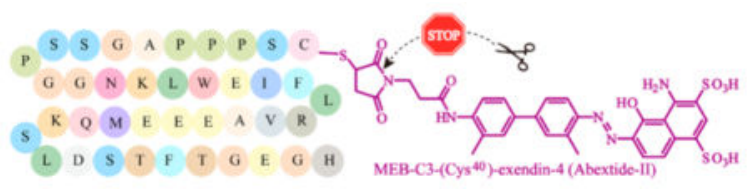

Type 2 diabetes mellitus (T2DM) is a multifactorial disease, which has two main characteristics: reduced insulin sensitivity linked to obesity and impaired insulin secretion due to $\beta$ cell dysfunction. ${ }^{1}$ When the demand for insulin finally overwhelms the capacity of the $\beta$ cells, ${ }^{2} \beta$ cell dysfunction will result in severe insulin secretion ${ }^{3}$ and $\beta$ cell death. ${ }^{4} \mathrm{~A}$

\footnotetext{
*Corresponding Authors: maqj@jlu.edu.cn. Phone: 301-451-4246. Fax: 301-435-4699. shawn.chen@nih.gov.

The authors declare no competing financial interest.

Supporting Information

The Supporting Information is available free of charge on the ACS Publications website at DOI: 10.1021/acs.bioconjchem.5b00625.

Supplemental figures of HPLC, LC-MS, and ${ }^{1} \mathrm{H}$ NMR results of compounds. The fluorescent lifetime study of Abextide II in the absence and presence of HSA. (PDF)
} 
number of drugs have been reported to enhance $\beta$ cell viability and restore their ability to synthesize and secrete insulin, but these drugs might also cause side effects such as hypoglycemia or weight gain. ${ }^{1}$ Therefore, it is very important to develop new methods and drugs to overcome the side effects in the treatment of type 2 diabetes mellitus.

Glucagon like peptide-1 (GLP-1) is a 30-amino-acid peptide hormone secreted from gut endocrine $\mathrm{L}$ cells in response to nutrient ingestion, and plays an important role in glucose homeostasis and nutrient metabolism. ${ }^{5}$ After binding to the GLP-1 receptor (GLP-1R) expressed in islet $a$ cells and $\beta$ cells, ${ }^{6}$ GLP-1 stimulates insulin secretion in a glucosedependent manner, which raises a negligible risk of hypoglycemia. ${ }^{7}$ Therefore, GLP-1R represents a viable therapeutic target to offer clinical benefits for type 2 diabetes mellitus. ${ }^{8,9}$ However, endogenous GLP-1 (half-lifetime about 1-2 min) is rapidly degraded by dipeptidyl peptidase-4 (DPP-4) once secreted. ${ }^{10}$ DPP-4 resistant and long-acting GLP-1R agonists have thus been developed. Exendin-4, a 39-amino-acid peptide which was originally isolated from Gila monster saliva, ${ }^{11}$ shares $53 \%$ amino acid sequence with mammalian GLP-1. ${ }^{12}$ Importantly, exendin-4 is resistant to DPP-4-mediated degradation. For example, the commercial Exenatide has a circulating half-life of 90-216 min. ${ }^{13}$

Although Exenatide has beneficial effects on reducing blood glucose level and enhanced half-life, the requirement for twice-daily injections limits the widespread use of this formula in the clinic. Because the kidney generally filters out molecules below $60 \mathrm{kDa}$, one method of reducing the clearance is to increase the molecular size of the protein drug. ${ }^{14}$ Albumin with a molecular weight of $66.5 \mathrm{kDa}$ is the most abundant protein in the blood circulation, and has an exquisitely long half-life time of 19 days in humans. ${ }^{15}$ Due to the extreme abundance in the blood circulation, albumin has the advantage of being used as an ideal drug carrier to prolong the retention of drug molecules in the circulation. ${ }^{16}$ Albumin-drug conjugates or prodrugs administered intravenously that bind in situ to circulating albumin, either noncovalently or covalently, have been developed. ${ }^{17,18}$ For instance, liraglutide, a C-16 acyl chain covalently modified analogue of GLP-1 with minor sequence alterations, extends its half-life by noncovalently interacting with albumin, but due to the loose interaction with HSA, once daily injection is still necessary. ${ }^{19}$ Albiglutide, a exendin-4albumin fusion protein, has a half-life time of 4-7 days and allows once a week administration. ${ }^{20}$ However, the recombinant fusion protein cannot be easily prepared and stored. It is thus necessary to develop new synthetic exendin-4 analogs that interact noncovalently with albumin and have prolonged circulation half-life.

Evans blue (EB) dye has been an important tool in many physiological and clinical investigations because of its high affinity for serum albumin. ${ }^{21}$ Recently we developed a truncated Evans blue dye (MEB) for macrocyclic chelator conjugation and labeling with a number of radioisotopes such as ${ }^{18} \mathrm{~F},{ }^{68} \mathrm{Ga}$, and ${ }^{64} \mathrm{Cu}$ for positron emission tomography (PET) and optical imaging of abnormal blood vessels, inflammation, myocardial infarction, lymph node mapping and tumor permeability, and so forth. ${ }^{22-24}$ One such in vivo albumin labeling probe ${ }^{68} \mathrm{Ga}-\mathrm{NOTA}-\mathrm{NEB}$ has been translated into the clinic for studying lymphatic system disorder and hemangioma. ${ }^{24}$ 
Previously, we prepared a maleimide modified truncated EB linked with the thiol group of $\left(\mathrm{Cys}^{40}\right)$ exendin-4 to obtain the MEB-(Cys $\left.{ }^{40}\right)$-exendin-4 (denoted as Abextide), which greatly improved the in vivo distribution pattern, pharmacokinetic, and pharmacodynamic characteristics of exendin- 4 in healthy BALB/c mice and in a diabetic rodent model $(\mathrm{db} / \mathrm{db}$ mice) ${ }^{25}$ However, thiol-maleimide of this structure might hydrolyze and transform to thiosuccinamic acid or original maleic and thiol compounds (Scheme 1). ${ }^{26-28}$

In this work, we synthesized a stable maleimide modified EB (MEB-C3-Mal) to conjugate with $\left(\mathrm{Cys}^{40}\right)$ exendin-4 to obtain a new MEB-C3-(Cys $\left.{ }^{40}\right)$ exendin-4 (denoted as Abextide II, Scheme 2), which showed good stability in both solution and powder forms at room temperature. Importantly, through effective binding with albumin, Abextide II showed better control of blood glucose level and longer hypoglycemic duration than the commercial Albiglutide at low doses in type 2 diabetic C57BL/6 db/db mice.

Abextide II was prepared from the compound MEB-NH $\mathrm{NH}_{2}$ in two steps. First, thiol reactive MEB-C3-Mal was obtained from the MEB- $\mathrm{NH}_{2}$ and 3-maleimidopropionic acid. Because the amino group of MEB- $\mathrm{NH}_{2}$ was not very active, the MEB- $\mathrm{NH}_{2}$ was allowed to react with 3-maleimidopropionic acid in the presence of PyBOP and excess DIPEA in DMF (70\% yield). The peaks at $3.93 \mathrm{ppm}(\mathrm{t}, J=6.8 \mathrm{~Hz}, 2 \mathrm{H})$ and $2.75 \mathrm{ppm}(\mathrm{t}, J=6.9 \mathrm{~Hz}, 2 \mathrm{H})$ belong to the double methylene $\left(-\mathrm{CH}_{2}-\right.$ ) groups (Figure $\mathrm{S} 1$ ), and the mass peak at 692.1 was attributed to [M-H] $]^{-}$of MEB-C3-Mal (calcd. for $\mathrm{C}_{31} \mathrm{H}_{27} \mathrm{~N}_{5} \mathrm{O}_{10} \mathrm{~S}_{2}, 693.1$ ). The thiol reactive MEB-C3-Mal was then allowed to react with $\left(\mathrm{Cys}^{40}\right)$ exendin-4 in PBS (pH 7.0) for 60 min to give desired Abextide II at a yield of 50\%. As shown in Figure S2, the mass peak at 4983 was attributed to $[\mathrm{M}-\mathrm{H}]^{-}$of Abextide II, and the mass peak at 4289.0 disappeared, suggesting that $\left(\mathrm{Cys}^{40}\right)$-exendin-4 was fully consumed.

Meanwhile, Abextide (Scheme S1) was also prepared for comparison. ${ }^{25} \mathrm{MEB}^{-\mathrm{NH}_{2}}$ was reacted with maleic anhydride in the presence of excess DIPEA in DMF, and then the purified intermediate was dehydrated and cyclized to form the MEB-Mal in acetic anhydride in $24 \%$ overall yield. When MEB-Mal-COOH was dehydrated to afford the cyclized MEB$\mathrm{Mal}$, the peaks at $6.42 \mathrm{ppm}(\mathrm{d}, J=13.6 \mathrm{~Hz}, 1 \mathrm{H})$ and $6.06 \mathrm{ppm}(\mathrm{d}, J=13.2 \mathrm{~Hz}, 1 \mathrm{H})$ were shifted to $6.99 \mathrm{ppm}(\mathrm{d}, J=2.5 \mathrm{~Hz}, 2 \mathrm{H})$ in the ${ }^{1} \mathrm{H}$ NMR (Figures S3,4). However, MEB-Mal was unstable and readily decomposed when it was kept at room temperature (Figure S5). The MEB-Mal should be used immediately to react with (Cys $\left.{ }^{40}\right)$ exendin- 4 in the PBS to synthesize MEB- $\left(\mathrm{Cys}^{40}\right)$ exendin-4 (Abextide).

With the same starting material MEB- $\mathrm{NH}_{2}$, the overall yields of Abextide II and Abextide were $\sim 31 \%$ and $\sim 12 \%$, respectively. This indicates that MEB-C3-Mal and Abextide II are more easily made with better yields than MEB-Mal and Abextide.

It was reported that the thiosuccinimide group might undergo hydrolysis to the iosuccinamic acid. The stabilities of Abextide and Abextide II were monitored by the HPLC and LC-MS. As shown in Figure 1a,b, when the saline solution of Abextide II was kept at room temperature for $24 \mathrm{~h}$, the HPLC peak showed complete conversion from a peak at $22.2 \mathrm{~min}$ to a new peak at $22.0 \mathrm{~min}$. The retention time changed from 4.54 to $4.39 \mathrm{~min}$ in LC-MS (Figure S6). Meanwhile, the mass peak was also converted from 4911.0 to 4929.0. The 
difference in mass value matched with the hydrolysis process from thiosuccinimides to thiosuccinamic acids. Thus, the new peak was attributed to the ring-opened thiosuccinamic acids Abextide-a or Abextide-b (Scheme 3). ${ }^{25}$

When the saline solution of Abextide II was kept at room temperature for $24 \mathrm{~h}$, there was no obvious new peak in the HPLC (Figure 1c,d). Meanwhile, the powder form of Abextide II was also kept at room temperature for 30 days, and no opening-ring thiosuccinamic acid product was observed by LC-MS (Figure S7). These data indicate that Abextide II is much more stable in both the solution and powder forms than Abextide.

The interaction between Abextide II and albumin was investigated by fluorescence and gel electrophoresis. As shown in Figure 2a, Abextide II alone had very low fluorescence emission. After adding HSA, the emission at $630 \mathrm{~nm}$ increased by over 20 -fold. The fluorescence lifetime of Abextide II in the absence and presence of HSA increased from 0.6 to $1.0 \mathrm{~ns}$ (Figure 2b). The substituent of azo group of Abextide II could rotate in the absence of HSA, which dissipates the energy and leads to the low emission. When the MEB binds with HSA, the rotation of MEB is restricted, and the energy dissipation is reduced to increase the fluorescence emission and lifetime.

As shown in Figure 2c, the mixture of HSA and Abextide II (middle) showed two spots in the bright-field. The higher retardation factor $\left(R_{\mathrm{f}}\right)$ spot should belong to the unbound Abextide II as it has similar $R_{\mathrm{f}}$ to that of pure Abextide II (right). The new spot should be attributed to the HSA/Abextide II complex with increased molecular weight. For fluorescence imaging, the green emission spot is Abextide II and the red spot is HSA/ Abextide II, which matched with the bright-field findings. Commassie blue staining showed that the new HSA/Abextide II spot was at the similar position with pure HSA. Collectively, these suggest that Abextide II binds effectively with HSA in vitro.

The hypoglycemic effects of exendin-4, Albiglutide, and Abextide II were examined in $\mathrm{db} / \mathrm{db}$ mice. The time vs blood glucose level curves of saline, exendin-4 $(25 \mathrm{nmol} / \mathrm{kg})$, Albiglutide ( $69 \mathrm{nmol} / \mathrm{kg})$, and Abextide II ( $25 \mathrm{nmol} / \mathrm{kg}$ ) after subcutaneous injection were plotted in Figure 3a. As shown in Figure 3b, at a dose of $25 \mathrm{nmol} / \mathrm{kg}$, the lowest glucose level in Exendin-4 treated mice was $10.25 \mathrm{mmol} / \mathrm{L}$, much higher than the regular blood glucose level $(8.35 \mathrm{mmol} / \mathrm{L}, p<0.05)$. At the dose of $14 \mathrm{nmol} / \mathrm{kg}$, the blood glucose level of the Albiglutide treated mice was as high as $11.88 \mathrm{mmol} / \mathrm{L}$ (Figure S8b). At the doses of 69 and $123 \mathrm{nmol} / \mathrm{kg}$, the lowest glucose levels were 7.03 (Figure 3b) and $6.67 \mathrm{mmol} / \mathrm{L}$ (Figure S8c), respectively. However, the lowest glucose level in Abextide II $(25 \mathrm{nmol} / \mathrm{kg})$ treated mice was reduced to $5.79 \mathrm{mmol} / \mathrm{L}$, and was much more effective than Albiglutide $(p<0.05)$ and exendin-4 $(p<0.01)$.

Meanwhile, the hypoglycemic duration in Abextide II $(25 \mathrm{nmol} / \mathrm{kg})$ treated mice was much greater; the time required to rebound to a glucose level of $8.35 \mathrm{mmol} / \mathrm{L}$ was $26 \mathrm{~h}$ as compared to $11 \mathrm{~h}$ for Albiglutide ( $69 \mathrm{nmol} / \mathrm{kg}$ ) (Figure $3 \mathrm{~b}$ ). At the dose of $123 \mathrm{nmol} / \mathrm{kg}$, the time required to rebound to $8.35 \mathrm{mmol} / \mathrm{L}$ for Albiglutide increased to $28 \mathrm{~h}$ (Figure $\mathrm{S} 8 \mathrm{~d}$ ), which was similar to that for Abextide II at a dose of only $25 \mathrm{nmol} / \mathrm{kg}$. Note that the mole amount of Albiglutide used was $\sim 5$-fold more than that of Abextide II, and the molecular 
weight of Albiglutide was 70-fold higher than that of Abextide II. As suggested, Abextide II showed better control of blood glucose level and longer hypoglycemic duration time than the commercial Exenatide and Albiglutide at the same dose.

In this work, we have developed a new EB modified exendin-4 peptide, Abextide II, in reasonably high yield, which displayed high stability in both solution and powder forms for easy storage. Through effective binding with albumin, Abextide II showed lower blood glucose level and longer hypoglycemic duration time than the commercially available Albiglutide in type 2 diabetic C57BL/6 db/db mice. Based on these results, we believe that Abextide II can be used to treat type- 2 diabetes. This strategy of stable MEB conjugation also holds the potential for the development of long-acting drugs other than exendin derivatives.

\section{Supplementary Material}

Refer to Web version on PubMed Central for supplementary material.

\section{Acknowledgments}

This work was supported by the National Science Foundation of China (81571708, 81501506), Research Fund of Science and Technology Department of Jilin Province (20150520154JH), Hygiene Specific Subjects of Jilin Province (SCZSY201508) and the Intramural Research Programs of the National Institute of Biomedical Imaging and Bioengineering, National Institutes of Health.

\section{References}

1. Hou S, Li C, Huan Y, Liu S, Liu Q, Sun S, Jiang Q, Jia C, Shen Z. Effects of E2HSA, a LongActing Glucagon Like Peptide-1 Receptor Agonist, on Glycemic Control and Beta Cell Function in Spontaneous Diabetic db/db Mice. J Diabetes Res. 2015; 2015:1.

2. Sachdeva MM, Claiborn KC, Khoo C, Yang J, Groff DN, Mirmira RG, Stoffers DA. Pdx1 (MODY4) regulates pancreatic beta cell susceptibility to ER stress. Proc Natl Acad Sci U S A. 2009; 106(45):19090-19095. [PubMed: 19855005]

3. Hosker JP, Rudenski AS, Burnett MA, Matthews DR, Turner RC. Similar reduction of first-and second-phase B-cell responses at three different glucose levels in type II diabetes and the effect of gliclazide therapy. Metab, Clin Exp. 1989; 38(8):767-772. [PubMed: 2668699]

4. Butler AE, Janson J, Bonner-Weir S, Ritzel R, Rizza RA, Butler PC. $\beta$-cell deficit and increased $\beta$ cell apoptosis in humans with type 2 diabetes. Diabetes. 2003; 52(1):102-110. [PubMed: 12502499]

5. Drucker DJ. Enhancing incretin action for the treatment of type 2 diabetes. Diabetes Care. 2003; 26(10):2929-2940. [PubMed: 14514604]

6. Holst JJ. The physiology of glucagon-like peptide 1. Physiol Rev. 2007; 87(4):1409-1439. [PubMed: 17928588]

7. Meloni A, DeYoung M, Lowe C, Parkes D. GLP-1 receptor activated insulin secretion from pancreatic $\beta$-cells: mechanism and glucose dependence. Diabetes, Obes Metab. 2013; 15(1):15-27. [PubMed: 22776039]

8. Moller DE. New drug targets for type 2 diabetes and the metabolic syndrome. Nature. 2001; 414(6865):821-827. [PubMed: 11742415]

9. Smyth S, Heron A. Diabetes and obesity: the twin epidemics. Nat Med. 2006; 12(1):75-80. [PubMed: 16397575]

10. Ørskov C, Wettergren A, Holst JJ. Biological effects and metabolic rates of glucagonlike peptide-1 7-36 amide and glucagonlike peptide-1 7-37 in healthy subjects are indistinguishable. Diabetes. 1993; 42(5):658-661. [PubMed: 8482423] 
11. Eng J, Kleinman W, Singh L, Singh G, Raufman J. Isolation and characterization of exendin-4, an exendin-3 analogue, from Heloderma suspectum venom. Further evidence for an exendin receptor on dispersed acini from guinea pig pancreas. J Biol Chem. 1992; 267(11):7402-7405. [PubMed: 1313797]

12. Göke R, Fehmann H-C, Linn T, Schmidt H, Krause M, Eng J, Göke B. Exendin-4 is a high potency agonist and truncated exendin-(9-39)-amide an antagonist at the glucagon-like peptide 1-(7-36)amide receptor of insulin-secreting beta-cells. J Biol Chem. 1993; 268(26):19650-19655. [PubMed: 8396143]

13. Kolterman OG, Kim DD, Shen L, Ruggles JA, Nielsen LL, Fineman MS, Baron AD. Pharmacokinetics, pharmacodynamics, and safety of exenatide in patients with type 2 diabetes mellitus. Am J Health-Syst Pharm. 2005; 62(2):173-181. [PubMed: 15700891]

14. Dennis MS, Zhang M, Meng YG, Kadkhodayan M, Kirchhofer D, Combs D, Damico LA. Albumin binding as a general strategy for improving the pharmacokinetics of proteins. J Biol Chem. 2002; 277(38):35035-35043. [PubMed: 12119302]

15. Peters, T. The Plasma Proteins Structure, Function, and Genetic Control. 2. Vol. 1. Elsevier; 2012. Serum Albumin; p. 133

16. Baggio LL, Huang Q, Brown TJ, Drucker DJ. A recombinant human glucagon-like peptide (GLP)-1-albumin protein (albugon) mimics peptidergic activation of GLP-1 receptor-dependent pathways coupled with satiety, gastrointestinal motility, and glucose homeostasis. Diabetes. 2004; 53(9):2492-2500. [PubMed: 15331566]

17. Havelund S, Plum A, Ribel U, Jonassen I, Vølund A, Markussen J, Kurtzhals P. The mechanism of protraction of insulin detemir, a long-acting, acylated analog of human insulin. Pharm Res. 2004; 21(8):1498-1504. [PubMed: 15359587]

18. Kim J-G, Baggio LL, Bridon DP, Castaigne J-P, Robitaille MF, Jetté L, Benquet C, Drucker DJ. Development and characterization of a glucagon-like peptide 1-albumin conjugate the ability to activate the glucagon-like peptide 1 receptor in vivo. Diabetes. 2003; 52(3):751-759. [PubMed: 12606517]

19. Feinglos M, Saad M, Pi-Sunyer F, An B, Santiago O. Effects of liraglutide (NN2211), a longacting GLP-1 analogue, on glycaemic control and bodyweight in subjects with type 2 diabetes. Diabetic Med. 2005; 22(8):1016-1023. [PubMed: 16026367]

20. Setji T, Feinglos M. Expert Rev Endocrinol Metab. 2013; 8(3):229-238.

21. Spahr P, Edsall JT. Amino acid composition of human and bovine serum mercaptalbumins. J Biol Chem. 1964; 239(3):850-854. [PubMed: 14154465]

22. Niu G, Lang L, Kiesewetter DO, Ma Y, Sun Z, Guo N, Guo J, Wu C, Chen XY. In vivo labeling of serum albumin for PET. J Nucl Med. 2014; 55(7):1150-1156. [PubMed: 24842890]

23. Wang Y, Lang L, Huang P, Wang Z, Jacobson O, Kiesewetter DO, Ali IU, Teng G, Niu G, Chen X. In vivo albumin labeling and lymphatic imaging. Proc Natl Acad Sci U S A. 2015; 112(1):208213. [PubMed: 25535368]

24. Zhang JJ, Lang LX, Zhu ZH, Li F, Niu G, Chen XY. Clinical translation of an ablbumin-biding PET radiotracer ${ }^{68}$ Ga-NEB. J Nucl Med. 2015; 56(10):1609-1614. [PubMed: 26251416]

25. Chen HJ, Wang GH, Lang LX, Jacobson O, Kiesewetter OD, Liu Y, Ma Y, Zhang XZ, Wu H, Zhu L, et al. Chemical conjugation of Evans blue derivative: a strategy to develop long-acting therapeutics through albumin binding. Theranostics. 2016; 6(2):243-253. [PubMed: 26877782]

26. Paris C, Brun O, Pedroso E, Grandas A. Exploiting protected maleimides to modify oligonucleotides, peptides and peptide nucleic acids. Molecules. 2015; 20(4):6389-6408. [PubMed: 25867825]

27. Baldwin AD, Kiick KL. Tunable degradation of maleimide-thiol adducts in reducing environments. Bioconjugate Chem. 2011; 22(10):1946-1953.

28. Lyon RP, Setter JR, Bovee TD, Doronina SO, Hunter JH, Anderson ME, Balasubramanian CL, Duniho SM, Leiske CI, Li F, et al. Self-hydrolyzing maleimides improve the stability and pharmacological properties of antibody-drug conjugates. Nat Biotechnol. 2014; 32(10):10591062. [PubMed: 25194818] 


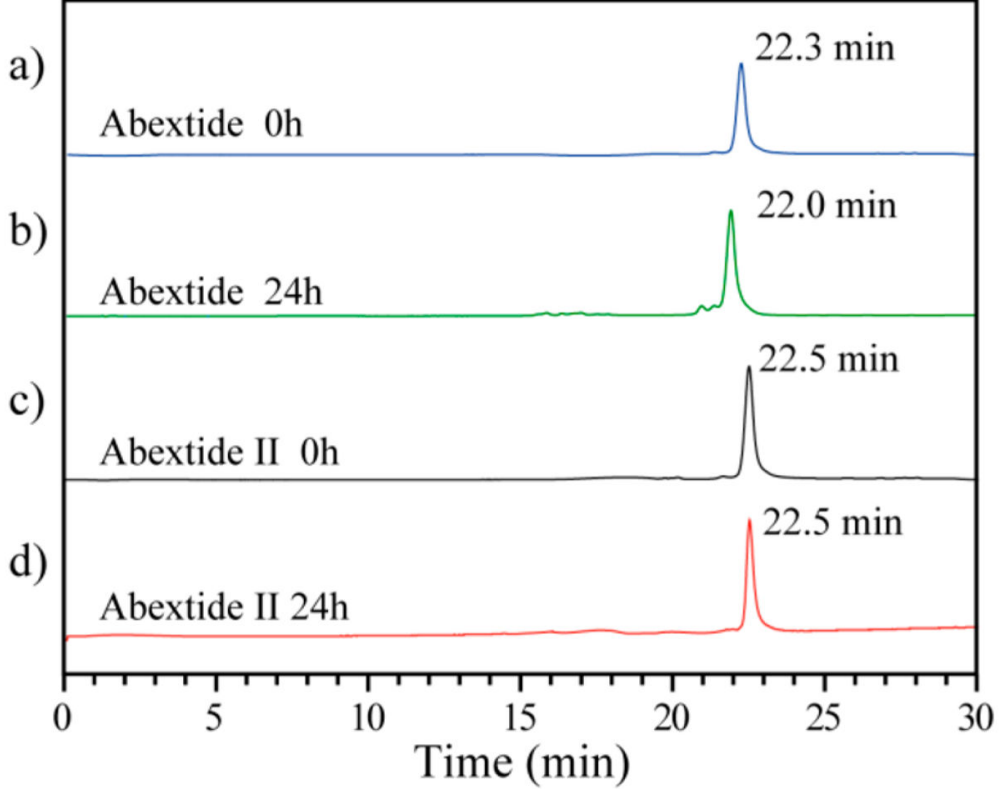

Figure 1.

HPLC spectra of the saline solutions of Abextide (a, b) and Abextide II (c, d) at room temperature for $0 \mathrm{~h}(\mathrm{a}, \mathrm{c})$ and $24 \mathrm{~h}(\mathrm{~b}, \mathrm{~d})$. 
a)
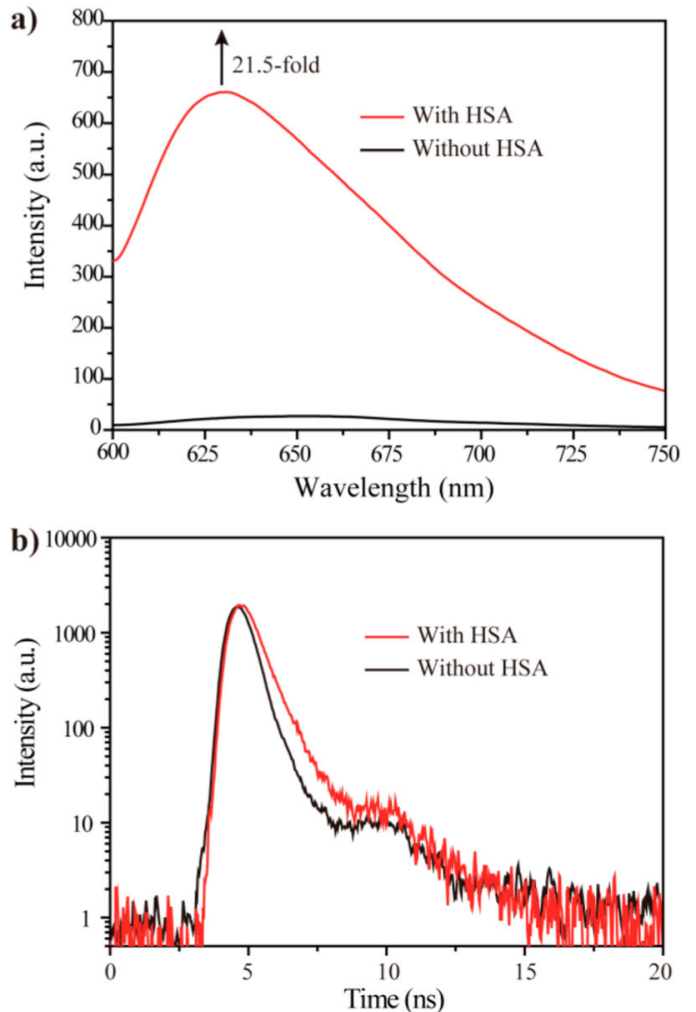

c)
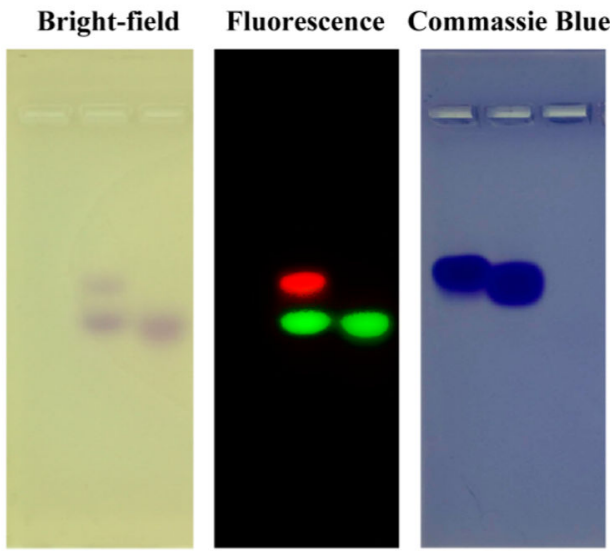

Figure 2.

(a) Fluorescence emission and (b) lifetime of MEB-C3-(Cys $\left.{ }^{40}\right)$ Exendin-4 in the absence (black line) and presence (red line) of HSA. (c) Agarose gel results of pure HSA (left), mixture of HSA and Abextide II (middle), and pure Abextide II (right). 

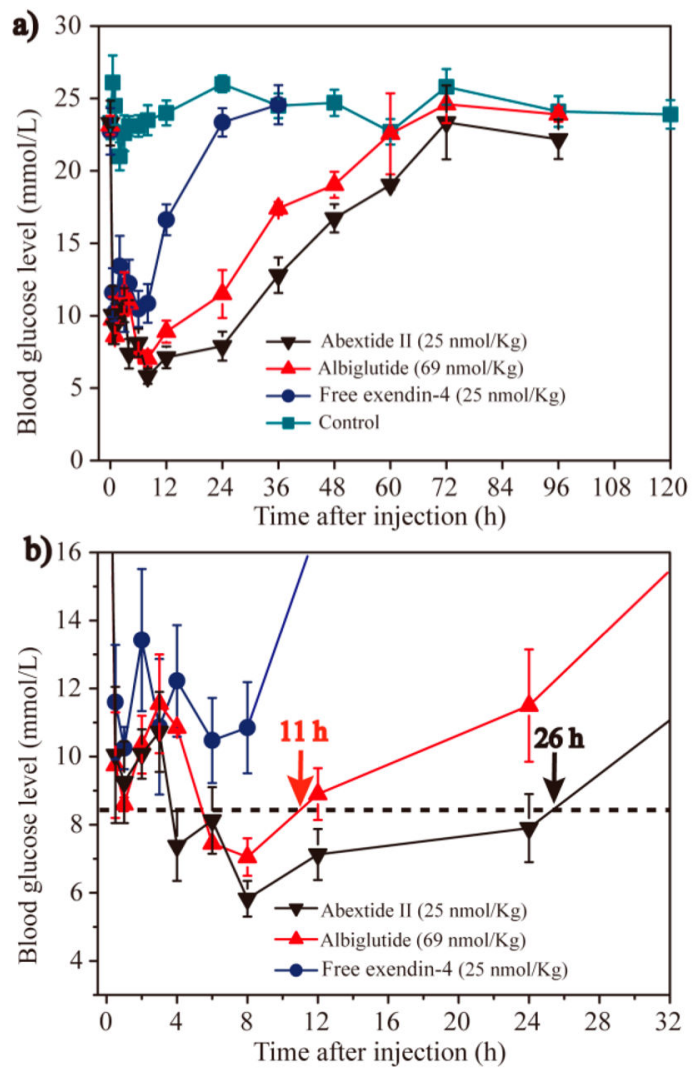

Figure 3.

(a) Hypoglycemic efficacies of free exendin-4 (25 nmol/kg), Albiglutide (69 nmol/kg), and Abextide II (25 nmol/kg) for $120 \mathrm{~h}$. Data represent three mice and are presented as mean \pm SDs. (b) Focused profile of (a), (0-32 h, 3-16 mmol/L). Times depict hypoglycemic duration rebound to $8.35 \mathrm{mmol} / \mathrm{L}$ (normal blood glucose level). 


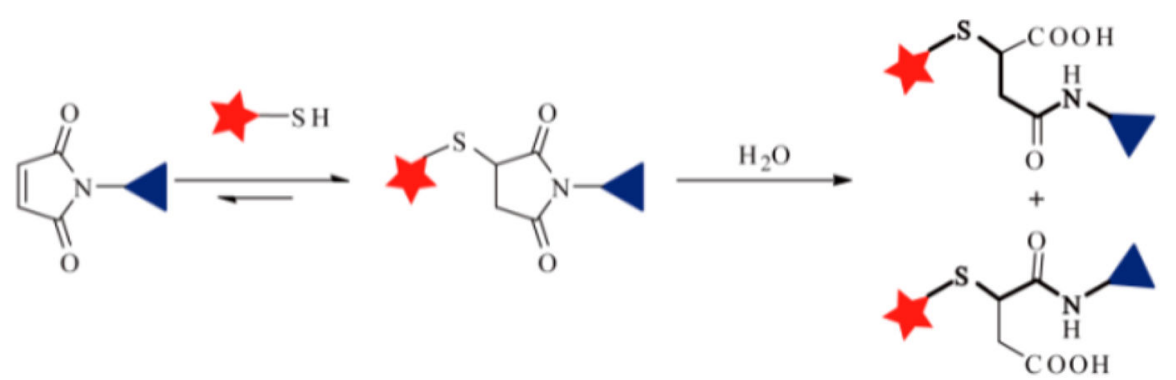

Scheme 1.

Thiol-Maleimide Reaction Generates Thiosuccinimide That Hydrolyzes in the Presence of Water 


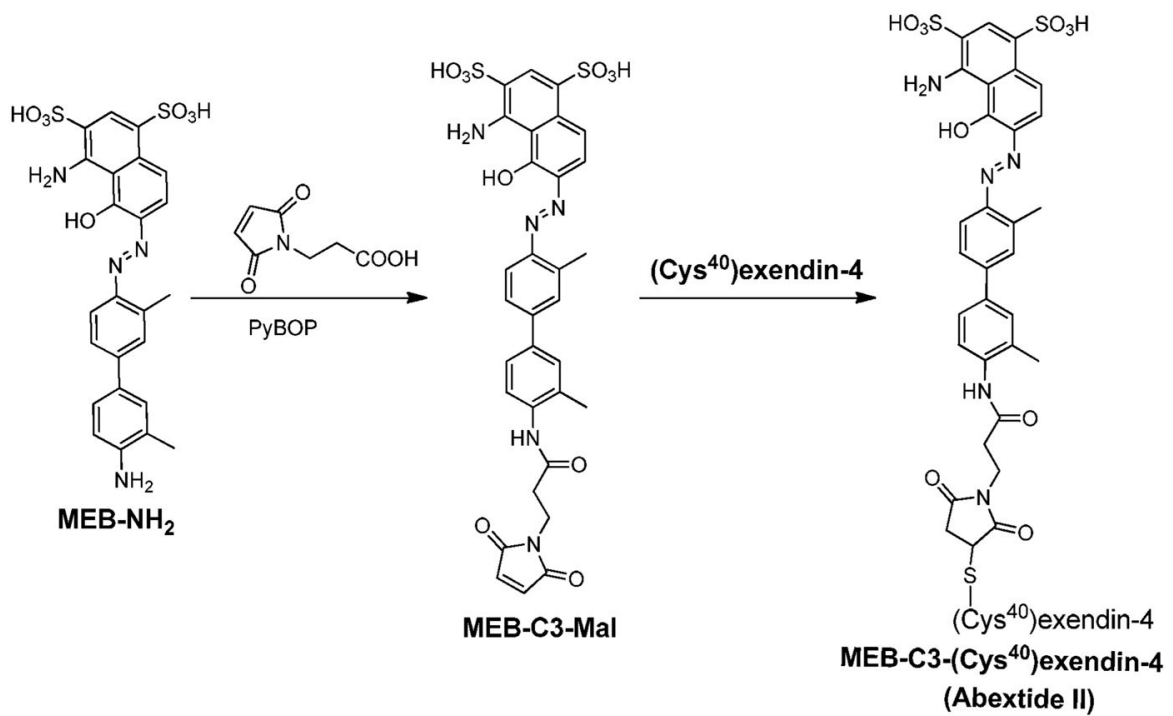

Scheme 2.

Synthetic Route of MEB-C3-(Cys $\left.{ }^{40}\right)$ exendin-4 (Abextide II) 

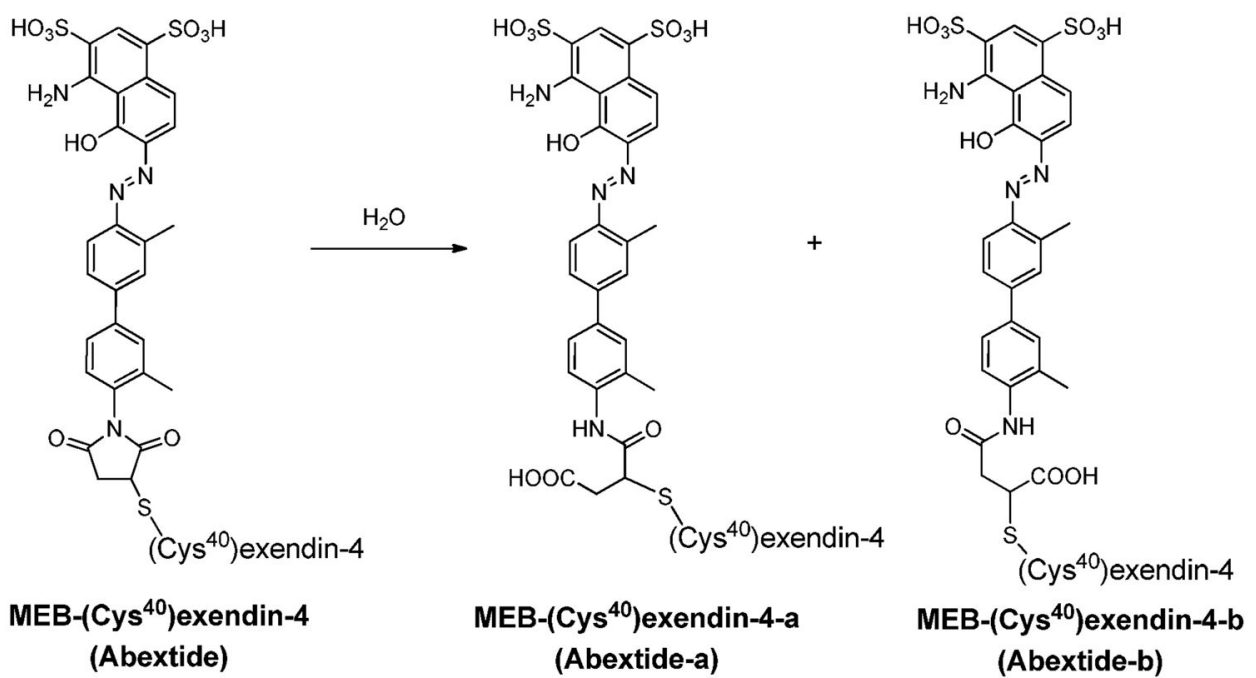

Scheme 3.

Hydrolytic Process of MEB-(Cys $\left.{ }^{40}\right)$ exendin-4 (Abextide) 